\title{
The Effects of Gender on the Attitudes towards the Computer Assisted Instruction: A Meta-analysis
}

\author{
Sefika Sumeyye Cam ${ }^{1}$, Gokhan Yarar $^{1}$, Cetin Toraman², Gurcu Koc Erdamar ${ }^{1}$ \\ ${ }^{1}$ Gazi Universty, Department of Educational Sciences, Ankara, Turkey \\ ${ }^{2}$ Counseling and Research Center, Ankara, Turkey \\ Correspondence: Sefika Sumeyye Cam, Gazi Universty, Department of Educational Sciences, Ankara, Turkey.
}

Received: April 2, 2016 Accepted: April 12, $2016 \quad$ Online Published: April 26, 2016

doi:10.11114/jets.v4i5.1515 URL: http://dx.doi.org/10.11114/jets.v4i5.1515

\begin{abstract}
The idea that gender factor creates a difference on computer usage and computer-assisted instruction is based upon previous years. At that time, it was thought that some areas like engineering, science and mathematics were for males so it created a difference on the computer usage. Nevertheless, developing technology and females becoming more active in information era alter this imbalance. About analyzing this kind of studies, significant differences exist on behalf of males in some studies, while significant differences exist on behalf of females in some studies, and there is no significant difference in terms of genders in other studies. While gender variable has been dealt as sub-variable in studies conducted with teachers in terms of learning/teaching activities, the number of meta-analyses investigating related teaching method according to gender is limited. In this study, meta-analysis method which gathers the results of different studies on the same specific topic and analyzing these findings statistically, is used. Comprehensive Meta Analysis (CMA) Statistic Program was used for statistical analysis. The data was analyzed by using the method of study effect meta-analysis. Gender factor is a crucial variable for learning and teaching activities. However, with this research, it becomes obvious that it is not such an important factor that can create a huge difference. Publication type, sample type and geographical region are determined as moderator variables with the thought that they can create a difference. Any difference cannot be identified according to publication and sample type at the end of the research.
\end{abstract}

Keywords: meta-analysis, gender, computer-assisted instruction

\section{Introduction}

Computers, which are essential in the era of technology and leave their marks on the $21^{\text {st }}$ century, are focused on educational areas as well as many other areas. Today, education utilizing computer assistance is improving and advancing. There are significant differences between the learning environments from the 1960's to 2010. The foremost of these differences is using technological devices in the classroom environment such as computers, smart boards, and tablets (Canbolat, 2011).

According to these developments, it can be said that computers have become smaller and more functional, especially in the last decade. Accordingly, their portability has improved resulting in an increase in frequency of occurrence in and out of the school (Shapka \& Ferrari, 2003). The benefit of instruction using computer assistance is incontrovertible if the utilization of educational opportunities and keeping up with the times is desired. According to Robyler (2003), researchers have revealed some terms about the usage of computers pertaining to education and instruction. "Computer-Assisted Education" (CAE) and "Computer-Assisted Instruction" (CAI) terms are common in activities utilizing computers for learning and teaching.

In literature, these two terms are not synonymous. The difference results from the conclusions drawn between educational and instructional notions. Education, which is a more comprehensive term compared to instruction, comprises all curricular and extracurricular activities. In this manner, computer-assisted education and the whole process from teaching a lesson by using a computer to saving lecture notes on a computer are included in the education. Computer-assisted instruction refers to teaching a lesson based on mutual interaction by using a computer. It refers to the learning environment which covers only the relevant lesson (Jones, 1995; Kucuk et al, 2014; Teo et al., 2015). In other words, computer-assisted education is a broader term which includes computer-assisted instruction. It can be said that $\mathrm{CAI}$ and $\mathrm{CAE}$ can be replaced thanks to this inclusive feature. 
The term computer-assisted education/instruction was introduced was introduced after the utilization of computers for teaching and learning. The combination of the visual, audial and interactive features of computers substantially increases their importance for education (Ornstein \& Lasley, 2004).

Yalin (2003) defines computer-assisted instruction as the usage of computers for reinforcing the acquired behaviors and teaching lessons by programming computers according to the system. Roblyer (2003) defines CAI as a supporting device making teaching and understanding easier during the instruction period. In other words, computer-assisted instruction means that computers are used for making the learning process more effective in instruction. According to Sahin and Yildirim (1999), CAI is a teaching method where computers are used in a learning environment and learners can utilize them according to their learning rate. From gathering computer technologies and principles of self-learning CAI is a method which strengthens student motivation and the teaching process. According to Usun (2004), CAI is a teaching method that uses computers as a supportive element so that learning can take place and learners can utilize them according to their learning rate. Thus, forming from gathering computer technologies and principles of self-learning CAI is a method which strengthens student motivation and teaching process.

No matter how it is defined, in computer-assisted instruction, it is essential that computers must be a complementary and strengthening device instead of a substitute for teaching (Demirel, Seferoglu \& Yagci, 2004). In short, teachers play a role in acquiring the defined goal and behaviors; computers play a role as supportive devices (Demirel, 2003; İsman, 2001; Ornstein \& Lasley, 2004). In this regard, computers are indispensable for modern-day education.

In reference to the usage of computers as instructional devices, teachers' behaviors pertaining to this subject result in significant variables. Some features such as computer skills time spent on the computer, and the attitudes towards computers affect the usage of computer-assisted instruction (Vannata \& Fordham, 2004). In developing information era, the features that all countries want to bring the teachers in are focused. In a global world, some skills like using computers as problem solving devices, utilizing them for active participation and intensifying teaching are expected from teachers (Teo et al., 2015). In that vein, while determining teaching proficiency, the Ministry of National Education states that teachers must have technology literacy skills (MEB, 2016). Some problems may arise in cases where instructors teach traditionally to students who use computers regularly in their daily life. In this regard, teachers' attitudes should be positive in order to be able to use computers in teaching/learning environments. Using computer-assisted instruction cannot be expected from a teacher who approaches computer assistance negatively and does not indigenize it (Pedraira \& Pear, 2015).

Many variables can affect the attitudes of teachers towards computer-assisted instruction usage, such as age, branch, seniority and gender (Kocasarac, 2003; Topcu, 2009; Teo et al., 2015). Therefore, numerous studies have been conducted (Basarici \& Ural, 2009; Andoh, 2012; Saricoban, 2013; Ates et al., 2016). Gender variable is remarkable because has been studied in most of the research. The idea that gender factor creates a difference on computer usage and computer-assisted instruction is based upon previous years. At that time, it was thought that some fields such as engineering, science and mathematics were for males and therefore created a difference on the computer usage (Ustundag, 2001). Thus, when the studies conducted before the 80's (Hess \& Muira 1985) were analyzed, it was found that males had more positive attitudes towards technology (Topcu, 2009). Nevertheless, developing technology and female participation in the information era alter this imbalance. When analyzing these studies, significant differences exist on behalf of males in some studies (Cetin \& Gungor, 2014), while significant differences exist on behalf of females in other studies (Kutluca \& Ekici, 2010; Kaplan et al., 2013). Conversely, there is no significant difference in terms of genders in other studies (Shapka \& Ferrari, 2003; Tuncer \& Tanas, 2011; Saricoban, 2013; Cakmak \& Taskiran, 2014; Kucuk et al., 2014; Teo et al., 2015; Ates et al., 2016).

While gender variable has been dealt with as a sub-variable in studies conducted with teachers in terms of learning/teaching activities, the number of meta-analyses investigating related teaching method according to gender is limited. One of them is the study conducted by Topcu (2009) investigating the effects of gender on computer attitudes. According to the findings of this study, there are a few differences according to Cohen's classification and there are nominal differences according to Thalheimer's classification in terms of gender. Additionally, Whittley (1997) investigates changes of attitudes and behaviors towards computer according to gender by conducting a meta-analysis. As a result, he reveals that gender in fact does not create any differences. Except from these above, there are no more comprehensive studies which investigate attitudes towards computer-assisted instruction in terms of gender at the national and international level. It is thought that this study will contribute the literature in this regard. Meta-analysis studies are needed for observing the big picture and obtaining more comprehensive results (Akgoz, Ercan \& Kan, 2004). As stated above, in some studies where gender factor is investigated as a sub-variable, results are on behalf of males while in some of them the results are on behalf of females. However, the important thing is looking at the general effect of the studies conducted in this area as a whole. Meta-analysis was used for determining whether there is a gender effect on attitudes towards computer-assisted instruction in learning and teaching activities. It was used for directing ongoing studies in this area. 
Meta-analysis studies, which assess several studies on a specific topic at the same time, are spreading like wildfire all around the world. Using meta-analysis is becoming more common in our country, especially in the medical and agricultural fields. However, in educational sciences these studies are less frequent (Kasarci, 2013 as cited in Sahin, 2005). Therefore, when looking at the studies on computer-assisted instruction, it can be observed that different variables have been applied and they are limited (the study on the effect of computer-assisted instruction about academic success (Camnalbur \& Erdogan, 2008), the study on the effectiveness of foreign language lessons with computer-assisted instruction method (Tomakin \& Yesilyurt, 2013), the study on the effect of computer-assisted mathematic instruction about academic success (Demir \& Basol, 2014)). From this point of view, it is thought that this study will contribute to meta-analysis studies on education in our country.

According to Topcu (2009), in our country and the world there is an impression that the attitudes of males towards computer are more positive than the attitudes of females. This impression needs to be supported using numerical values. This study aims to gather the results of different studies on attitudes of teachers and pre-service teachers towards computer-assisted instruction and investigate the gender factor. These are the research questions:

1. What effect does gender have on the attitudes of teachers and pre-service teachers towards computer-assisted instruction?

2. Are there any significant differences between influence quantities according to participants (teachers and pre-service teachers) who are involved in the sample?

3. Are there any significant differences between influence quantities according to publication type?

4. Are there any significant differences between influence quantities according to geographical region that studies are conducted?

\section{Method}

In this study, the meta-analysis method which gathers the results of different studies on the same specific topic and analyzes these findings statistically, is used. The analysis is conducted for reaching a new and general result by combining statistical findings from independent studies (Dincer, 2014). In general terms, Figure 1 schematizes the process steps of a meta-analysis.

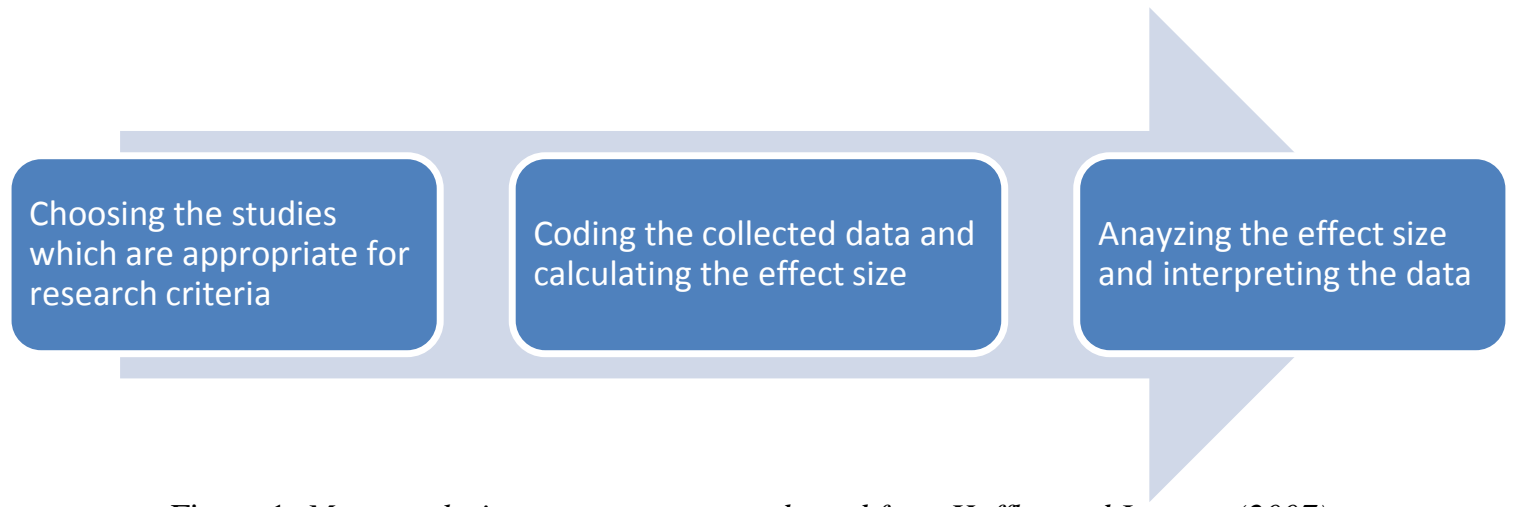

Figure 1. Meta-analysis process steps are adopted from Hoffler and Leutner (2007).

In these general terms, inclusion criteria, making a literature review and coding methods are mentioned below. After that, analysis of the data is explained.

\subsection{Inclusion Criteria, Making a Literature Review and Coding Methods}

Master thesis and PhD dissertations in Turkey were examined in order to determine the effect of gender on teachers' and pre-service teachers' attitudes towards computer-assisted instruction. In order to reach the related studies, "computer-assisted instruction", "attitude", "teacher" and "pre-service teacher" key words were used. The studies which are included into the research were reached by using Google Scholar search engine, Tubitak Ulakbim Dergi Park, and Council of Higher Education National Thesis Center data bases. While determining the sources which will be included, there were some requirements such as the sample being conducted in Turkey and conducted by Turkish researchers. The studies which are not open to public access or where the full version cannot be reached were not included into the research. It was crucial that the studies were empirical and male-female groups were independent variables in order to obtain the effect size. For male-female teacher groups; sample size, mean, standard deviation values were studied in order to calculate the effect size which is needed for meta-analysis study. After this elimination process, the research was conducted with 36 studies which include 19 articles, 16 master theses, and $1 \mathrm{PhD}$ dissertation. During literature review, it was seen that the first study on this subject was in 2000 and the last study was in 2015 . So the studies 
(2000-2015) appropriate to the coding criteria were involved into the research.

\subsection{Coding Period}

First of all, each study was examined according to the study criteria from the beginning. After that, information which is suitable for coding protocol was designed for every study. In coding protocol, there are three parts; "study identity" showing study's name, year, authors and publication type, "study content" showing sample content and range of application, "study data" showing sample size, means, standard deviations.

\subsection{Validity of the Research}

Expert opinions were asked about the points to be considered on coding while the data was analyzed for persuasiveness of the research. The scanning process was repeated by researchers at different places and times. Findings confirmed each other. While coding, all summary information was written so that any mistakes could not happen and the researchers checked and confirmed by analyzing them separately.

\subsection{Data Analysis}

Comprehensive Meta Analysis (CMA) Statistic Program was used for statistical analysis. The data was analyzed by using the method of study effect meta-analysis. In this method, the aim is to calculate the differences between the mean of experiment and control groups (Borenstein, Hedges \& Rothstein 2007). 0.05 was chosen as the significance level of statistical analysis. For determining the heterogeneity, which is the first step of data analysis, Chi-Square Test (Q statistics) with (q-1) degree of freedom was suggested by Cochran (1954). According to the results of the heterogeneity test, effect sizes are calculated by using fixed effect model or random effect model. If effect sizes show homogeneous distribution, fixed effect model is used. If effect sizes do not show homogeneous distribution, random effect model is used (Dincer, 2014).

Moderator variables were determined as sample type, geographical region and publication type in the research. According to teachers and pre-service teachers, a change deriving from teaching experiences can be seen. According to the geographical conditions, a change deriving from different opportunities of the learning/teaching process can be seen. Because time and the number of participants can affect the results, these three moderators and the scope of the study were considered.

Effect size classifications which are often used in literature were used in this research and are given below:

The classification belongs to Cohen (1988):

$\mathrm{d}=0,20-0,50$ low level (small)

$\mathrm{d}=0,50-0,80$ medium level (medium)

$\mathrm{d}=0,80<\mathrm{d}$ high level (large)

More detailed classification compared to Cohen belongs to Thalheimer and Cook (2002):

$-0.15<\mathrm{d}<0.15$ non-significant level (negligible, trivial)

$0.15<\mathrm{d}<0.40$ low level (small)

$0.40<\mathrm{d}<0.75$ medium level (medium)

$0.75<\mathrm{d}<1.10$ high level (large)

$1.10<\mathrm{d}<1.45$ very high level (very large)

$1.45<$ d perfect level (huge)

\section{Findings}

\subsection{Study Characteristics}

In this research investigating the effect of gender on the attitudes towards computer-assisted instruction, general characteristics and effect sizes of studies were determined by using the number of samples, mean and standard deviation of 36 studies. The data was obtained from total 7326 participants 3297 males and 4029 females.

In the research, three moderators were focused on such as publication type, geographical region and sample type. Table 1 shows descriptive statistic belonging to these moderators. 
Table 1. Descriptive Statistics about Studies Investigating the Effect of Gender on Attitudes towards Computer-Assisted Instruction

\begin{tabular}{lll}
\hline Variables & Levels & n \\
\hline Publication Type & Article & 19 \\
& Master thesis & 16 \\
& PhD dissertation & 1 \\
\hline Geographical Region & Central Anatolia & 9 \\
& Marmara & 9 \\
& Aegean & 4 \\
& Eastern Anatolia & 6 \\
& Southeastern Anatolia & 1 \\
& Mediterranean & 3 \\
& Black Sea & 4 \\
\hline Sample Type & Teacher & 16 \\
& Pre-service Teachers & 20 \\
\hline
\end{tabular}

According to publication type; there are 19 articles, 16 master theses and $1 \mathrm{PhD}$ dissertation. While analyzing the studies according to geographical region; there are 9 studies in Central Anatolia, 9 studies in Marmara, 6 studies in Eastern Anatolia, 4 studies in Black Sea, 4 studies in Aegean, 3 studies in Mediterranean and 1 study in Southeastern Anatolia. These studies are close to each other in terms of the sample type distribution. There are 16 teachers and 20 pre-service teachers in the study.

\subsection{Findings about Whether Gender Creates a Difference on Attitude towards Computer-assisted Instruction or Not}

In meta-analysis studies, effect sizes can be determined by using various methods. Random effect methods and fixed effect methods can be used for calculating the effect size. The selection of the method depends on the accepted hypothesis. The choice of random or fixed effect method is about the homogeneous or heterogeneous distribution assumptions of studies. Thus, heterogeneity test must be done before the calculation of effect size. According to heterogeneity testing; $Q$ statistic is calculated and $p$ value which is significance level of $Q$ statistic is interpreted. If $p$ is significant, there is significant difference between studies resulting in heterogeneity. In this situation, using fixed effect model is not appropriate. Random effect model gives truer effect size value in case of heterogeneity. If $p$ is not significant, there is no significant difference between studies making the results homogeneous. In this situation, using fixed effect model is more preferable (Akgoz et al., 2004, Dincer, 2014).

In this regard, first of all, heterogeneity test was analyzed. According to heterogeneity test result $\left(\mathrm{Q}_{(34)}=112,642, \mathrm{p}<.05\right)$; the studies are heterogeneous among them. The level of heterogeneity was determined as $\% 70\left(\mathrm{I}^{2}=\% 69,816\right)$. Random effect model was used because the studies are heterogeneous.

Studies included in the research were analyzed one by one before determining mean effect size. Meta-analysis diagram (forest plot) was formed for analyzing the unified effect size of the studies (Figure 1). In this diagram, effect sizes and confidence intervals can be seen separately. Under the graphic, mean effect size according to random effect model can be seen. There are positive (+) and negative (-) studies according to effect size when they are analyzed one by one. Based on this finding, there are studies stating that females were more positive towards computer-assisted instruction and vice versa. In the research, male is chosen as the reference group. The studies with positive (+) effect sizes are on behalf of males while the studies with negative (-) effects sizes are on behalf of females. The size and thickness of plus mark show the wideness of confidence interval. The longer horizontal line of plus mark is, the wider confidence interval of the study is (Borenstein, Hedges \& Rothstein 2007; Dincer, 2014).

According to the diagram shown in Figure 2; widest confidence interval belongs to Yilmaz and Alici (2011) and Telli (2009), lowest confidence interval belongs to Cobanoglu (2005). When the studies are analyzed one by one, it can be seen that 17 studies are negative and 19 studies are positive. However, total effect size of the research is on the positive side. According to this as shown in Table 2, the studies found that positive attitudes on behalf of males are more although mean effect size is not significant (Gozuyesil \& Dikici, 2014 as cited in Wolf, 1986).

Table 2. Findings about meta-analysis effect size according to random effect model

\begin{tabular}{|c|c|c|c|c|c|c|c|c|}
\hline \multirow{2}{*}{$\begin{array}{l}\text { Effect } \\
\text { (ES) }\end{array}$} & \multirow{2}{*}{ Size } & \multirow[t]{2}{*}{$\mathbf{Z}$} & \multirow[t]{2}{*}{$\mathbf{p}$} & \multirow[t]{2}{*}{$\mathbf{Q}$} & \multirow[t]{2}{*}{$\mathbf{I}^{2}$} & \multirow{2}{*}{$\begin{array}{l}\text { Standard } \\
\text { Error (SE) }\end{array}$} & \multicolumn{2}{|c|}{ \% 95 Confidence Interval } \\
\hline & & & & & & & Lower Limit & Upper Limit \\
\hline 0,031 & & 0,657 & 0,511 & 112,668 & 68,935 & 0,047 & $-0,062$ & 0,124 \\
\hline
\end{tabular}

$* p<.05, * * p<.01, * * * p<.001$

In Table 2, the mean effect size of included studies in random effect model according to gender variable ES=0,031, Standard error of mean effect size 0,047, upper limit of confidence interval of mean effect size 0,124 and lower limit $-0,062$ are calculated. Calculated mean effects size value is not significant $(Z=0,657, p>.05)$. In this case, it is revealed that there is no difference between male and female about attitudes towards computer-assisted instruction. 


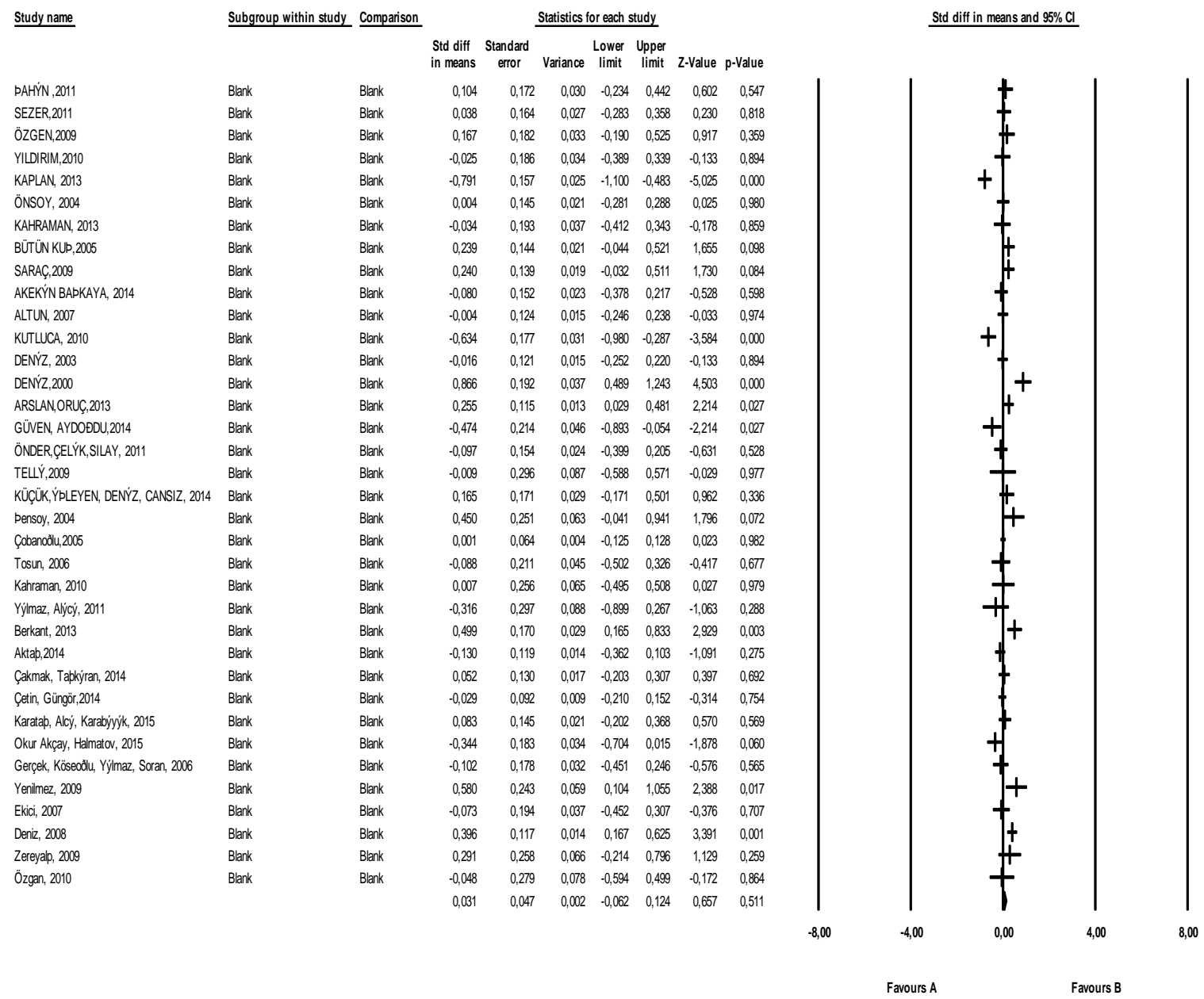

Figure 2. The gender effect on attitudes towards computer-assisted teaching forest plot

\subsection{Publication Bias}

The practice of publishing only studies with significant results is widespread. It is known that including only these studies into meta-analysis leads to publication bias. Additionally, bias of included studies can reduce the validity of that study (Borenstein, Hedges \& Rothstein 2007; Ustun \& Eryilmaz, 2014). One of the ways of measuring the publication bias is creating a funnel plot. According to funnel plot, all studies are expected to be placed in funnel lines symmetrically. The studies which are out of the funnel lines lead to a publication bias. The more scattering the number of studies which are out of the lines, the more publication bias there is (Dincer, 2014). There is a funnel plot of publication bias below. 


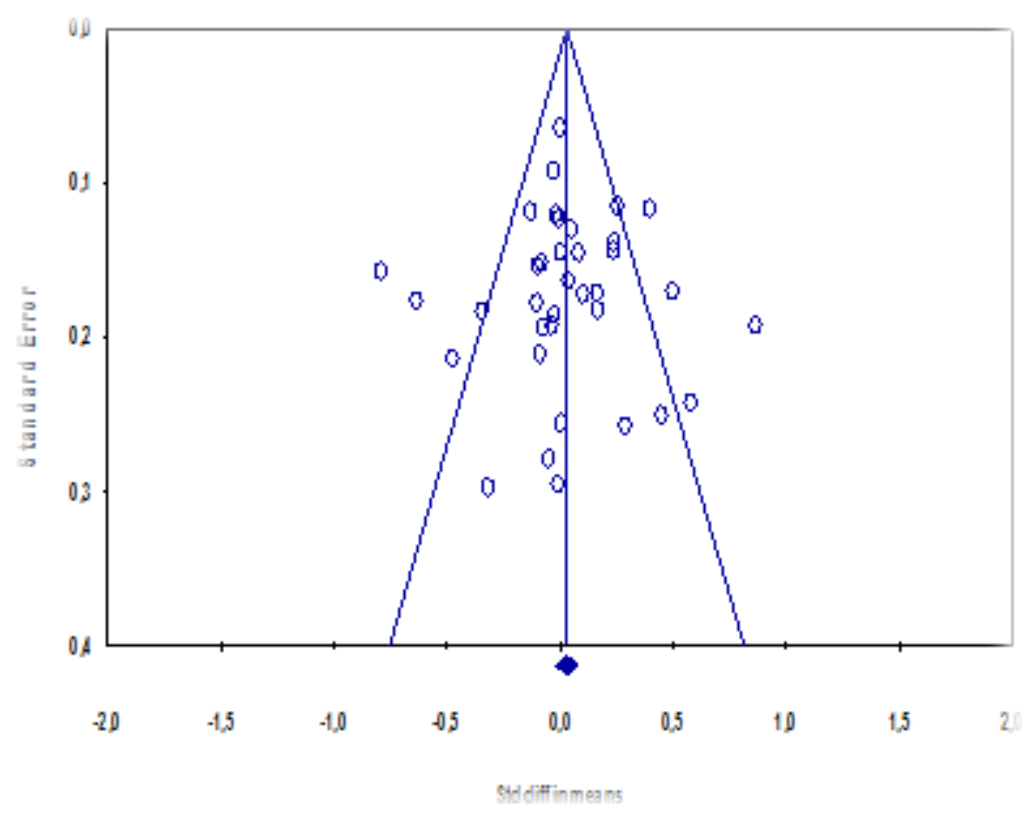

Figure 3. Funnel plot of publication bias

When looking at Figure 3, it can be seen that most of the studies are inside of the lines. In this case, it can be said that included studies contribute to the meta-analysis.

When the funnel plot is analyzed, it can be seen that symmetry is irregular and the studies on the left hand side are more numerous insomuch as there are some studies out of the lines of funnel plot. This creates heterogeneity. When it is analyzed by Duval and Tweedie's trim and fill technique, it is understood that 6 studies should be moved to the right side from the left side for symmetry. The new mean effect size after the moving process will be 0,120 .

3.4 Investigating the Effects of Gender on Attitudes towards Computer-assisted Instruction According to Moderator Variables

In Table 3, moderator variables which are publication type, sample type and geographical region effect are examined.

Table 3. The effect of gender on attitudes towards computer-assisted instructions (moderator variables)

\begin{tabular}{lllllllllll}
\hline $\begin{array}{l}\text { Moderator } \\
\text { Variables }\end{array}$ & $\begin{array}{l}\text { Moderator } \\
\text { Variable Levels }\end{array}$ & $\mathbf{N}$ & $\mathbf{E S}$ & $\mathbf{S E}$ & $\mathbf{Z}$ & $\mathbf{p}$ & $\begin{array}{l}\text { Lower } \\
\text { Limit }\end{array}$ & $\begin{array}{l}\text { Upper } \\
\text { Limit }\end{array}$ & Q & sd \\
\hline $\begin{array}{l}\text { Publication } \\
\text { type }\end{array}$ & article & 19 & 0,033 & 0,076 & 0,434 & 0,665 & $-0,116$ & 0,182 & \\
& Master Thesis & 16 & 0,031 & 0,060 & 0,515 & 0,607 & $-0,087$ & 0,149 & 0,010 & 2 \\
& PhD & 1 & 0,007 & 0,256 & 0,027 & 0,979 & $-0,495$ & 0,508 & \\
\hline Sample type & Teacher & 16 & 0,040 & 0,069 & 0,582 & 0,561 & $-0,095$ & 0,176 & 0,032 \\
& Pre-service & 20 & 0,023 & 0,068 & 0,340 & 0,734 & $-0,110$ & 0,156 & \\
& teacher & & & & & & & & \\
\hline Geographical & Central Anatolia & 9 & 0,038 & 0,084 & 0,455 & 0,649 & $-0,127$ & 0,204 & \\
Region & Marmara & 9 & 0,198 & 0,099 & $\mathbf{2 , 0 0 6 *}$ & 0,045 & 0,005 & 0,391 & \\
& Aegean & 4 & $-0,015$ & 0,053 & $-0,292$ & 0,771 & $-0,119$ & 0,088 & \\
& East & 6 & $-0,140$ & 0,154 & $-0,914$ & 0,361 & $-0,441$ & 0,161 & 7,373 & 6 \\
& Southeastern & 1 & 0,167 & 0,182 & 0,917 & 0,359 & $-0,190$ & 0,525 & & \\
& Mediterranean & 3 & 0,201 & 0,223 & 0,902 & 0,367 & $-0,236$ & 0,639 & \\
& Black Sea & 4 & $-0,177$ & 0,177 & $-1,000$ & 0,318 & $-0,525$ & 0,170 &
\end{tabular}

$* p<.05, * * p<.01, * * * p<.001$

When the table is analyzed, there is a significant difference $(\mathrm{p}<.05)$, in terms of geographical region variable and there is no significant difference according to the publication and sample type $(p>.05)$. It can be seen that the geographical region which has the highest mean effect size is Marmara and it is on behalf of males.

\section{Discussion, Result and Suggestions}

36 studies were included in this study focusing on the effect of gender on attitudes towards computer-assisted instruction. The data was collected and combined from two sample group as 3297 males and 4029 females -a total of 
7326 participants. A meta-analysis was conducted in order to find a general result.

The results were reached by using the random effect model because there is heterogeneity among the studies. According to this, there is no significant effect of gender on the attitudes towards computer-assisted instruction. According to Topcu (2009); in our country, males' attitudes towards computers are more positive compared to females. However, when it comes to the results of his study, little difference, according to Cohen, and insignificant difference, according to Thalheimer emerged. Another study which supports the result of Topcu's (2009) study is Whittley's study (1997). Whittley (1997) confirmed that there is no gender effect on the attitude and behavior towards computers. From this point of view, it can be interpreted that the impression that attitudes of males in Turkey are more positive towards computer and computer-assisted instruction has no scientific basis. With the developing technological era, now every individual can utilize computers and computer-assisted instructions. It is obvious that this situation has nothing to do with gender. Therefore considering the gender factor is useless while analyzing the attitude in every computer-assisted instruction study.

According to the results of publication bias, most of the included studies are in the lines of the funnel, but not symmetrically. This situation can lead to a thought that there is publication bias. Manifestos presented in the congress or symposium not published or a situation when the data of these studies is unavailable results in the file drawer problem (Ustun and Eryilmaz, 2014). Not including and not publishing the studies which have no significant results or of which data is unavailable to the analysis causes the publication bias. In this regard, if other manifesto studies and studies which are considered as not published because of the lack of significant statistic results can be gathered, reanalysis can be done.

Publication type, sample type and geographical region are determined as moderator variables with the presumption that they can create a difference. Any difference cannot be identified according to publication and sample type at the end of the research. So, it can be said that time and sample numbers do not create a difference in articles and theses. Likewise, there is no difference between teachers and pre-service teachers deriving from experience. In a fast developing technology era, age and experience are now closer to each other resulting in a smaller gap between them. Nonetheless, according to geographical region analysis, there is little difference on behalf of males in the Marmara region according to the classification of Thalheimer and Cook (2005).

The gender factor is a crucial variable for learning and teaching activities. However, with this research, it becomes obvious that this factor does not create a huge difference. Every teacher and pre-service teacher comes to the classroom environment with similar preparedness for computers. The results of Whitley's meta-analysis study (1997) confirm this inference. In his study which was conducted with adults and university students, he proposes that there is no relevance between gender and attitudes towards computers. The studies which were conducted during those years in our country demonstrate that there was a significant difference on behalf of males (Ustundag, 2001). However, it is obvious that females are interested in technology and computers now. This case should affect the teaching/learning environment.

\section{References of Studies Included in Analysis}

Akcay, N. O., \& Halmatov, M. (2015). Okuloncesi ogretmen adaylarının bilgisayar destekli egitim yapmaya iliskin tutumlarının incelenmesi (The research of preschool teacher candidates' attitudes towards the use of computer assisted education), Trakya Universitesi Egitim Fakultesi Dergisi, 5(1), 44-50.

Aktas, O. (2014). Ogretimde bilgisayar destekli ogretim ve bilgi teknolojisi sintflarının (Bilgisayar laboratuvarlarınin) kullanımı konusundaki ogretmen tutum ve gorusleri: adana ili ornegi (Computer assisted instruction in the primary school and the use of computer labs in teacher attitudes and views: Adana sample), (Unpublished master's thesis). Retrieved from: http://tez.yok.gov.tr

Altun, S. (2007). Ilkogretim okullarinda calisan ogretmenlerin bilgisayar kullanma becerileri ve bilgisayar destekli ogretime iliskin tutumlart uzerine bir arastırma (Bartın Ili Ornegi) (Attitudes of teachers working in primary schools towards their ability to use computer and the computer aided instruction (Sample of Bartin) ), (Unpublished master's thesis). Retrieved from: http://tez.yok.gov.tr

Arslan, A., \& Ayse, O. (2013). Ilkogretim ogretmenlerinin etkilesimli egitim CD'lerine yonelik tutum ve gorusleri (The attitudes and opinion of primary school teachers about interactive CD's), Turkiye Sosyal Arastırmalar Dergisi, 172(172), 313-326.

Baskaya, A. A. (2014). Ilkogretimde gorev yapan brans ogretmenlerinin bilgisayar destekli egitime iliskin tutumlarının incelenmesi (The research of the attitude of middle school branch teachers concerning computer aided education). (Unpublished master's thesis). Retrieved from: http://tez.yok.gov.tr

Berkant, H. G. (2013). Ogretmen adaylarının bilgisayara yonelik tutumlarının ve oz-yeterlik algılarının ve bilgisayar destekli egitim yapmaya yonelik tutumlarının bazı degiskenler acısından incelenmesi (Investigation of preservice 
teachers' attitudes and perceived self-efficacies toward Computer and their attitudes toward computer supported education in terms of some variables). Journal of Instructional Technologies \& Teacher Education, 2(2), 11-22.

Cakmak, Z., \& Taskıran, C. (2014). Sosyal bilgiler ogretmen adaylarının bilgisayar destekli egitime yonelik tutumlarının cesitli degiskenlere gore incelenmesi (Examination in terms of various variables of the attitudes of teacher candidates social studies towards computer assited training). Turkish Studies - International Periodical for the Languages, Literature And History Of Turkish Or Turkic, 9(5), 529-537.

Cetin, O., \& Gungor, B. (2014). Ilkogretim ogretmenlerinin bilgisayar oz-yeterlik inancları ve bilgisayar destekli ogretime yonelik tutumları (Computer Self-Efficacy Beliefs of Primary School Teachers and Their Attitudes towards Computer-Aided Instruction). Ondokuz Mayls University, The Journal of Education Sciences, 33(1), 55-78.

Cobanoglu, I. (2005). Ege Universitesi ve Dokuz Eylul Universitesi ogrencilerinin bilgisayar destekli ogretime yonelik tutumları (The attitudes of Ege University and Dokuz Eylul University Students' towards computer assisted instruction). (Unpublished master's thesis). Retrieved from: http://tez.yok.gov.tr

Deniz, L. (2000). Prior computer experiences and computer attitudes of preservice teachers (Ogretmen adaylarının bilgisayar yasantıları ve bilgisayar tutumları). Marmara University Ataturk Education Faculty, The Journal of Education Sciences, 12,135-166.

Deniz, L. (2003). Ogretmen adaylarının bilgisayar yasantıları ve bilgisayar tutumları arasındaki iliskiler (The relations between the prior computer experiences of preservice teachers' and their attitudes). Marmara Universitesi Ataturk Egitim Fakultesi Egitim Bilimleri Dergisi, 18, 39-64.

Deniz, S. (2008). Ilkogretim okullarında gorev yapan ogretmenlerinin bilgisayar destekli egitime iliskin tutumları ve bilgisayarın ogrenci basarısı uzerindeki rolunun degerlendirilmesi (The attitudes of elementary school teachers about education with computer supported and the influence of computer on students' success). (Unpublished master's thesis). Retrieved from: http://tez.yok.gov.tr

Ekici, Y. (2007). Afyonkarahisar ilinde gorev yapan din kulturu ve ahlak bilgisi ogretmenlerinin bilgisayar destekli egitime iliskin tutumları ve bu tutumları etkileyen faktorler (The attitudes of religious culture and ethic course teachers, working in Afyonkarahisar city, towards computer assited learning and the factors affecting these attitudes). (Unpublished master's thesis). Retrieved from: http://tez.yok.gov.tr

Gercek, C., Koseoglu, P., Yılmaz, M., \& Soran, H. (2006). Ogretmen adaylarının bilgisayar kullanımına yonelik tutumlarının cesitli degiskenler acisından incelenmesi (An analyses of the attitudes of teacher candidates towards computer use). Hacettepe Universitesi Egitim Fakultesi Dergisi, 30(30), 130-139.

Guven, E., \& Aydogdu, M. (2014). Determination of candidate science teachers' attitudes towards computer assisted teaching. Procedia-Social and Behavioral Sciences, 116, 3564-3567.

Kahraman, E. (2013). Turkce ogretmenlerinin bilgisayar destekli egitim ve teknolojiye yonelik tutumlarl arasindaki iliskinin incelenmesi (Turkish teachers' attitudes towards computer education and technology of the relationship between ). (Unpublished master's thesis). Retrieved from: http://tez.yok.gov.tr

Kahraman, S. (2010). Atomun yapıs ve orbitaller konusunda gelistirilen uc boyutlu bilgisayar destekli ogretim materyallerinin ogretmen adaylarinin basartsl ve tutumlarina etkisi (The effect of three-dimensional computer assisted instruction materials developed for the atomic structure and orbitals on the successand attitudes of undergraduates). (Unpublished doctoral dissertation). Retrieved from: http://tez.yok.gov.tr

Kaplan, A., Ozturk, M., Altaylı, D., \& Ertor, E. (2013). Sinıf ogretmenlerinin bilgisayar destekli ogretime yonelik tutumlarının bazı degiskenlere gore karsılastırılması (Comparing the attitudes of classroom teachers computer aided instruction (CAI) according to some variables). Turkish Journal of Computer and Mathematics Educationc (TURCOMAT), 4(2), 89-103.

Karatas, H., Alcı, B., \& Karabıyık, B. (2015). Ogretmen adaylarının bilgisayar destekli egitime iliskin tutumları (Attitudes of pre-service teachers to computer asisted education). Egitim ve Ogretim Arastirmaları Dergisi, 4(3), $1-9$.

Kucuk, B., Isleyen, T., Deniz, D., \& Cansız, S. (2014). Matematik ogretmeni adaylarının bilgisayar destekli egitime yonelik tutumlarının incelenmesi (Research of Attitudes Toward Computer Aided Education of Mathematics Teacher Candidates). Kuramsal Egitimbilim Dergisi, 7(2), 212-223. 
Kus, B. B. (2005). Ogretmenlerin bilgisayar oz-yeterlik inancları ve bilgisayar destekli ogretime yonelik tutumları (Teachers' perceived computer self-efficacy and their attitudes on computer based instruction). (Unpublished master's thesis). Retrieved from: http://tez.yok.gov.tr

Kutluca, T., \& Ekici, G. (2010). Ogretmen adaylarının bilgisayar destekli egitime iliskin tutum ve oz-yeterlik algılarının incelenmesi (Examining teacher candidates' attitudes and self-efficacy perceptions towards the computer assisted education). Hacettepe Universitesi Egitim Fakultesi Dergisi, 38, 177-188.

Onder, F., Celik, P., \& Silay, I. (2011). Attitude of teacher candidates toward making computer supported education. Procedia Computer Science, 3, 967-971.

Ozgan, V. (2010). Din kulturu ve ahlak bilgisi ogretmenlerinin bilgisayar destekli egitime iliskin tutumları ve bu tutumları etkileyen faktorler (Approaches and attitudes of teology teachers against computer enhanced teaching and the factors that affect these approaches - Edirne sample). (Unpublished master's thesis). Retrieved from: http://tez.yok.gov.tr

Ozgen, K., Obay, M., \& Bindak, R. (2009). Ortaogretim matematik ogretmen adaylarının bilgisayar ve bilgisayar destekli egitime yonelik tutumlarını incelenmesi (Research on secondary mathematics teachers' attitudes towards computer and computer aided education). Dicle Universitesi Sosyal Bilimler Enstitusu Dergisi, 1(2), 12-24.

Ozsoy, S. (2004). Student's And Teacher's Attitudes Towards The Use Of Computer-Assisted Language Learning at the Preaparatory School of Celal Bayar University. (Unpublished master's thesis). Retrieved from: http://tez.yok.gov.tr.

Sahin, A., \& Akcay, A. (2011). Turkce ogretmeni adaylarının bilgisayar destekli egitime iliskin tutumlarının incelenmesi (An analysis of Turkish language teachers candidates attitudes towards computer assisted education). .Electronic Turkish Studies, 6(2), 909-918.

Sarac, B. (2009). Istanbul ili Umraniye ilcesindeki meslek liselerinde gorev yapan ogretmenlerin bilgisayar destekli egitime iliskin tutumları (The attitudes of the teachers, teaching at the vocational high schools in Umraniye, Istanbul, towards computer assited learning). (Unpublished master's thesis). Retrieved from: http://tez.yok.gov.tr

Sensoy, O. (2004). Ilkogretim okullarındaki ogretmenlerin bilgisayar oz-yeterlilik algıları ile bilgisayar destekli ogretim yonteminin yararına iliskin inancları arasındaki iliski (The relation between the computer self-efficacy perceptions and the benefits of computer aided teaching methods of teachers in primary schools). (Unpublished master's thesis). Retrieved from: http://tez.yok.gov.tr

Sezer, A. (2011). Cografya ogretmeni adaylarının bilgisayar destekli egitime iliskin tutumlarının incelenmesi (Examining geography teachers candidates attitudes towads the computer assisted education). Usak Universitesi Sosyal Bilimler Dergisi, 4(1), 1-19.

Telli, E. (2009). Uc boyutlu sanal materyallerin ogretmen adaylarının bilgisayar dersindeki basarılarına ve bilgisayar destekle ogretime yonelik tutumlarına etkisi (The effect of 3D virtual materials on the success of the teacher candidates in the course of computer and their attitudes towards computer assisted teaching). (Unpublished master's thesis). Retrieved from: http://tez.yok.gov.tr

Tosun, N. (2006). Bilgisayar destekli ve bilgisayar temelli ogretim yontemlerinin, ogrencilerin bilgisayar dersi basarıs1 ve bilgisayar kullanım tutumlarına etkisi: Trakya Universitesi Egitim Fakultesi ornegi (The effects of computer assisted and computer based methods on the success of the students and the attitude of using computer in computer classses: A sample study at education faculty of Trakya). (Unpublished master's thesis). Retrieved from: http://tez.yok.gov.tr

Yenilmez, K. (2009). Ogretmen adaylarının bilgisayar destekli matematik ogretimi dersine yonelik gorusleri (Teacher candidates' opinion about the computer aided mathematics instruction course). Sosyal Bilimler Dergisi Sayl, 21, 207-220.

Yildirim, S., \& Kaban, A. (2010). Ogretmen adaylarının bilgisayar destekli egitime karsı tutumları (Attitudes of teacher candidates towards the computer assisted education). Uluslararası Insan Bilimleri Dergisi, 7(2), 158-168.

Yilmaz, N., \& Alici, S. (2011). Investigating pre-service early childhood teachers' attitudes towards the computer based education in science activities.TOJET: The Turkish Online Journal of Educational Technology, 10(3), 161-167.

Zereyalp, S. A. (2009). EFL Teacher Educators Attitudes towards CALL: Case of Turkish State Universities. (Unpublished master's thesis). Retrieved from: http://tez.yok.gov.tr 


\section{References}

Akgoz, S., Ercan, I., \& Kan, I. (2004). Meta-analiz (Meta-analysis). Uludag Universitesi Tip Fakultesi Dergisi, 30(2), 107-112.

Akyuz, Y. (2008). Turk egitim tarihi (History of Turkish Education). Ankara: Pegem Akademi Yayınları.

Andoh, C. B. (2012). Factors influencing teachers' adoption and integration of information and communication technology into teaching: A review of the literature. International Journal of Education and Development Using Information and Communication Technology (IJEDICT), 8(1), 136-155.

Ates, A. M., Delil, A., Islak, A. G. O., \& Savcı, U. Z. (2016). Pedagojik formasyon egitimine katılan ogretmen adaylarının bilgisayar destekli ogretim ile ilgili tutumlarının degerlendirilmesi (An evaluation of the attitudes of the preservice teachers that participate in the pedagogical formation programs towards computer aided instruction). Celal Bayar Universitesi Sosyal Bilimler Dergisi, 13(4), 99-214.

Basarıc1, R., \& Ural, A. (2009). Bilgisayar ogretmen adaylarının bilgisayar destekli egitime yonelik tutumları (Attitudes of computer teacher candidates related to computer-aided education). International Online Journal of Educational Sciences, 1(1), 165-176.

Borenstein, M., Hedges, L., \& Rothstein, H. (2007). Meta-analysis: Fixed effect vs. random effects. Retrieved from: https://www.meta-analysis.com

Cakmak, Z., \& Taskıran, C. (2014). Sosyal bilgiler ogretmen adaylarının bilgisayar destekli egitime yonelik tutumlarının cesitli degiskenlere gore incelenmesi (Examination in terms of various variables of the attitudes of teacher candidates social studies towards computer assited training). Turkish Studies - International Periodical For The Languages, Literature And History Of Turkish Or Turkic, 9(5), 529-537.

Camnalbur, M., \& Erdogan, Y. (2008). A meta analysis on the effectiveness of computer-assisted instruction: Turkey sample. Kuram ve Uygulamada Egitim Bilimleri, 8(2), 497.

Canbolat, N. (2011). Matematik ogretmen adaylarının teknolojik pedagojik alan bilgileri ile dusunme stilleri arasındaki iliskinin incelenmesi (A research on the interaction between technological pedagogical content knowledge and thinking styles of mathematics teacher candidates). (Unpublished master's thesis). Retrieved from: http://tez.yok.gov.tr

Cetin, O., \& Gungor, B. (2014). Ilkogretim ogretmenlerinin bilgisayar oz-yeterlik inancları ve bilgisayar destekli ogretime yonelik tutumları (Computer Self-Efficacy Beliefs of Primary School Teachers and Their Attitudes towards Computer-Aided Instruction). Ondokuz Mayls Universitesi Egitim Fakultesi Dergisi, 33(1), 55-78.

Cohen, J. (1988). Statistical power analysis for the behavioral sciences (2 nd. edition). New Jersey: Lawrence Erlbaum Associates, Inc. http://books.google.com.tr/Access date: 03.02.2016.

Demir, S., \& Basol, G. (2014). Effectiveness of Computer-Assisted Mathematics Education (CAME) over Academic Achievement: A Meta-Analysis Study. Educational Sciences: Theory \& Practice, 14(5), 2026-2035.

Demirel, O. (2003). Ogretim Teknolojileri ve Materyal Gelistirme (Instruction Technologies and Material Development). Ankara: Pegem Yayıncılık

Demirel, O., Seferoglu, S., \& Yagc1, E. (2001). Ogretim Teknolojileri ve Materyal Gelistirme (Instruction Technologies and Material Development). Ankara:,Pegem Yayınc1lık.

Dincer, S. (2014). Egitim Bilimlerinde Uygulamall Meta-Analiz (Meta-Analysis of Applied Science in Education). Ankara:,Pegem Yayıncılık.

Gozuyesil, E., \& Dikici, A. (2014). Beyin temelli ogrenmenin akademik basarıya etkisi: Bir meta-analiz calısması (The effect of brain based learning on academic achievement: A Meta-Analytical Study). Kuram ve Uygulamada Egitim Bilimleri. 14(2), 629-648.

Hoffler, T., \& Leutner, D. (2007). Instructional animation versus static pictures: A meta-analysis. Learning and Instruction, 17(6), 722-738.

Isman A. (2001). Bilgisayar ve egitim (Computer and education), Sakarya Universitesi Egitim Fakultesi Dergisi, 2(1), $1-34$.

Jones, R. (1995). Implementing a system in the global village. Education+ Training, 37(1), 27-32.

Kaplan, A., Ozturk, M., Altaylı, D., \& Ertor, E. (2013). Sinıf ogretmenlerinin bilgisayar destekli ogretime yonelik tutumlarının bazı degiskenlere gore karsilastırılması (Comparing the attitudes of classroom teachers computer aided instruction (CAI) according to some variables). Turkish J. Comput. Mathe. Educ, 4(2), 89-103.

Kasarcı, I. (2013). Proje tabanlı ogrenme yaklasımının ogrencilerin akademik basarı ve tutumlarına etkisi: bir 
meta-analiz calısması (The effectiveness of project based learning on students academic achivements and attitudes: A meta-analysis). (Unpublished master's thesis). Retrieved from: http://tez.yok.gov.tr

Kocasarac, H. (2003). Bilgisayarlarin ogretim alaninda kullanimina iliskin ogretmen yeterlilikleri (Teacher qualifications for the use of computers in teaching areas), Online Journal TOJET: The Turkish of Educational Technology, 2(3), 77-85.

MEB (2016). Ogretmenlik Meslegi Genel Yeterlilikleri Kitabı (The Book Of Teacher's General Competencies), Access date: 17.02.2016. http://otmg.meb.gov.tr/YetGenel.html.

Ornstein, A. C., \& Lasley, T. J.(2004). Strategies for Effective Teaching (4th ed.).New York, NY: McGraw-Hill.

Pedreira, K., \& Pear, J. (2015). Motivation and Attitude in a Computer-Aided Personalized System of Instruction Course on Discrete-Trials Teaching. Journal on Developmental Disabilities, 21(1), 45-51.

Roblyer, M. S. (2003). Integrating educational technology into teaching (3rd ed.). Columbus, $\mathrm{OH}$ : Merrill Prentice Hall.

Sahin, T. Y., \& Yıldırım, S. (1999). Ogretim Teknolojileri ve Materyal Gelistirme (Instruction Technologies and Material Development), Ankara: Anı Yayınc1lık.

Sarıcoban, A. (2013). Pre-service ELT teachers' attitudes towards computer use: A Turkish survey. Eurasian Journal of Educational Research, 53, 59-78.

Shapka, J. D., \& Ferrari, M. (2003).Computer-Related Attitudes and Actions of Teacher Candidates, Computers in Human Behavior, 19(3), 319-334.

Teo, T. (2008). Pre-service teachers' attitudes towards computer use: A Singapore survey. Australasian Journal of Educational Technology, 24(4), 413-424.

Teo, T., Fan, X., \& Du, J. (2015). Technology acceptance among pre-service teachers: Does gender matter. Australasian Journal of Educational Technology, 31(3), 235-251.

Thalheimer, W., \& Cook, S. (2002). How to calculate effect sizes from published research articles: A simplified methodology. http://work-learning.com/effect_sizes.htm. Access date: 03.02.2016.

Tomakin, E., \& Yesilyurt, M. (2013). Bilgisayar destekli yabancı dil ogretim calısmalarının meta analizi: Turkiye ornegi (Meta-analysis of computer assisted foreign language learning studies: A sample of Turkey). Yuzuncu Yll Universitesi Egitim Fakultesi Dergisi, 10(1), 248-263.

Topcu, P. (2009). Cinsiyetin Bilgisayar Tutumu Uzerindeki Etkisi: Bir Meta-analiz Calismasi (The impact of gender on computer attitudes: A Meta-Analsis Study) (Unpublished master's thesis). Retrieved from: http://tez.yok.gov.tr

Tuncer, M., \& Tanas, R. (2011). Egitim Fakultesi ogrencilerinin bilgisayar oz-yeterlik algılarının degerlendirilmesi (Evaluation of the computer self efficacy perceptions of students from faculty of education). Adiyaman Universitesi Sosyal Bilimler Enstitusu Dergisi, 4(6), 222-232.

Ustun, U., \& Eryılmaz, A. (2014). Etkili arastırma sentezleri yapabilmek icin bir arastırma yontemi: meta-analiz (A research methodology to conduct effective research syntheses: Meta-Analysis). Egitim ve Bilim, 39(174), 1-32.

Ustundag, N. (2001). Mufredat laboratuar okullarında gorev yapan yonetici ve ogretmenlerin bilgisayar tutumları ile kayg1 duzeyleri arasındaki iliskinin incelenmesi (The relation between the anxiety levels and the computer attitudes of the principals and the teachers who work in curiculum laboratuary). Marmara Universitesi, Egitim Bilimleri Enstitusu Yayınlanmamıs Yuksek Lisans Tezi, Istanbul.

Usun, S. (2004). Bilgisayar Destekli Ogretimin Temelleri (Foundations of computer assisted instruction). Ankara: Nobel Yayincilik.

Vannata, R. A., \& Fordham, N. (2004). Teacher Dispositions as predictors of classroom technology use. Journal Of Research On Technology Education, 36(3), 25-271.

Whitley, B. E. (1997). Gender differences in computer-related attitudes and behavior: A meta-analysis. Computers in Human Behavior, 13(1), 1-22.

Yalın, H. I. (2003). Ogretim Teknolojileri ve Materyal Gelistirme (Instruction Technologies and Material Development). Ankara: Pegem Yayincilik. 